М. А. Курушина

\title{
ЗІСТАВНИЙ АНАЛІЗ СТАРИХ ТА СУЧАСНИХ ПРІЗВИЩ ПОЛТАВЩИНИ
}

Курушина М. А. Зіставний аналіз старих та сучасних прізвищ Полтавщини.

У статті подано класифікацію прізвищевих назв XVII ст. і сучасних. Проаналізовані основні типи мотиваційних основ, виявлені особливості найменувань обох періодів.

Ключові слова: прізвище, мотивація, семантика, словотвір.

Курушина М. А. Сравнительный анализ древних и современных фамилий Полтавщины.

В статье представлена классификация фамильных названий XVII в. и современных. Проанализированы основные типы мотивационных основ, показаны особенности наименований обоих периодов.

Ключевые слова: фамилия, мотивация, семантика, словообразование.

Kurushina M.A. Comparative analyses of the old and modern surnames of Poltava region.

The classification of the old and modern surnames were performed in the work with taking into account double motivation. The specific of both periods is shown.

Key words: surname, motivation, semantic, derivation.

Упродовж тривалого часу власні назви є предметом зацікавлення не тільки мовознавців, а й філософів, істориків, соціологів, етнологів, географів тощо. Ономастичні дослідження дають цінний матеріал для суміжних із лінгвістикою наукових напрямів. Крім того, оніми зазнають постійного поповнення, межі між апелятивною і пропріальною лексикою 
часом $є$ дуже рухливими. Деякі класи онімів швидше, ніж лексика загальна, відбивають мовні процеси або ж навпаки довше зберігають давні форми. Цим, власне, і зумовлена постійна увага науковців до власних назв. На сьогодні можна говорити про всебічне дослідження українського ономастичного матеріалу під різними кутами зору. Традиційними є роботи 3 етимології, семантики, словотвору власних назв. Останнім часом з'явилися й спроби застосування когнітивного підходу.

Антропоніми загалом і прізвища зокрема $є$ найбільш популярним класом для вивчення. Початки наукового вивчення прізвищ пов'язані 3 іменами А. Степовича «Заметка о происхождении и склонении малорусских фамилий» (1882р.), М. Сумцова «Малорусские фамильные прозвания» (1885 р.), Й. Ролле «Powstavanie nazwisk rodowych u ludu maioruskiego. Sylvetka heraldyczno-etnograficzna» (1889 р.), К. Кахникевича «Імена і прозвища та їх походженє» (1891р.), В. Ястребова «Малорусские прозвища Херсонской губернии. Этнографический очерк» (1893р.), В. Охрімовича «Знадоби до познання народних звичаїв і поглядів правних» (1895р.), I. Франка «Причинки до української ономастики» (1906р.), М. Корниловича «Огляд народних родових прізвищ на Холмщині $\mathrm{i}$ Підляшші» (1926р.). Системне дослідження українських антропонімів припадає на другу половину XX - початок XXI ст. і представлено роботами Л. Гумецької, М. Демчук, М. Худаша, Ю. Редька, А Свашенко, Р. Керсти, Р. Осташа, І. Сухомлина, О. Неділько, І. Желєзняк, С. Бевзенка, П. Чучки тощо. Низка дисертацій присвячена вивченню регіональної антропоніміки (Г. Бучко, С. Панцьо, І. Фаріон, Л. Тарновецька, Б. Близнюк, Г. Панчук, Л. Кравченко).

Попри наявність великої кількості наукових робіт, у яких описується українська антропонімія, усе ж не всі території охоплені такими дослідженнями, що зумовлює фрагментарність загальної картини й унеможливлює висновки. Уведення нового антропонімного матеріалу до наукового обігу значно розширює уявлення про систему іменування в українській та інших слов'янських мовах. Розширення географії й часу дослідження прізвищ сприятиме удосконаленню знань про український ономастикон і лексику загалом. Крім того, результати таких робіт можуть бути використані при створенні атласів та довідників 3 української антропоніміки. Порівняльний аналіз антропонімів різних періодів дозволяє зробити висновки про розвиток прізвищ.

Наша розвідка присвячена зіставному аналізу старих та сучасних прізвищ Полтавщини переважно в семантичному аспекті. Зважаючи на тісний зв'язок семантики й словотвору, принагідно подаємо міркування про словотвірні особливості номенів. Для дослідження були застосовані такі фактичні матеріали: «Реєстр усього війська Запорізького 1649 року...» (списки козаків Миргородського полку Уцтивицької сотні (120 одиниць) найближча територіально) та сучасні реєстри жителів с. Білоцерківка 
Велико-Багачанського району Полтавської області (64 одиниці). Попри давність антропонімних досліджень у науковій літератури немає узгодженості щодо деяких термінопозначень; таке твердження зокрема стосується давніх форм номінування осіб, що функційно наближені до сучасних прізвищ. Безперечно, українська система іменування особи зазнавала трансформації в процесі розвитку, тому пропоновані для розгляду давні антропоніми умовно називаємо, услід за Р. Осташем, «прізвищевими назвами» (ПН), оскільки таке позначення, на наш погляд, відбиває особливості цих одиниць із погляду функціонування.

Залежно від значення основи умовно поділяємо назви обох періодів на такі групи: 1) патронімічні (матронімічні) прізвища (ПН); 2) прізвища $($ ПН), що утворилися внаслідок функційних змін нехрещених імен; 3) етнічні та відтериторіальні; 4) професійні; 5) прізвища (ПН), утворені за певною характерною особливістю першого носія. Слід зазначити, що семантичний та словотвірний аналіз як сучасних, так і давніх прізвищ тісно пов'язані. Особливо це стосується назв, похідних від неканонічних імен. Більше того, певна частина номенів має подвійну, а інколи й потрійну мотивацію основи.

До першої групи належать 65 ПН та 22 сучасні прізвища, серед яких $\epsilon$ одиниці, утворені від різних основ. Так, від канонічного імені чи його форми походять такі ПН: Артемий, Артема $\rightarrow$ Артюха $\rightarrow$ Артюшенко; Василии $\rightarrow$ Вас(ь)ко $\rightarrow$ Ващенко; Григории $\rightarrow$ Гриц(ь) $\rightarrow$ Гриценъко (3 одиниці); Григории $\rightarrow$ Гришко $\rightarrow$ Грищенко; Іоаннъ $\rightarrow$ Іван $\rightarrow$ Иванєнъко; Ігнатии $\rightarrow$ Ігнат $\rightarrow$ Ігнатєнко; Карпъ $\rightarrow$ Карьпєнъко; Кирикъ $\rightarrow$ Кирєчєнко; Константинъ $\rightarrow$ Костантинъ $\rightarrow$ Кость $\rightarrow$ Костенъко; Лесь $\rightarrow$ Лесєнъко (2 одиниці); Лука $\rightarrow$ Луценъко $\rightarrow$ (3 одиниці); Макарий $\rightarrow$ Макар $\rightarrow$ Макаренъко; Маркъ $\rightarrow$ Марчєнъко; МатӨей $\rightarrow$ МатАшъ $\rightarrow$ Матяшєнъко; Мина $\rightarrow$ Минєнко; Смилианъ $\rightarrow$ Омелян $\rightarrow$ щмєлянєнко; Онуфрий $\rightarrow$ Онопрей $\rightarrow$ щнуприєнко; Петрь $\rightarrow$ Петренъко Филиппь $\rightarrow$ Пилип $\rightarrow$ Пилипєнко; Симеонъ $\rightarrow$ Сємєон $\rightarrow$ Семен $\rightarrow$ Сємєнєнко; Улас $\rightarrow$ Уласєнъко; Иустинъ (?) $\rightarrow$ Устим/(н) $\rightarrow$ Устыменъко; Феодоръ $\rightarrow$ Федоръ

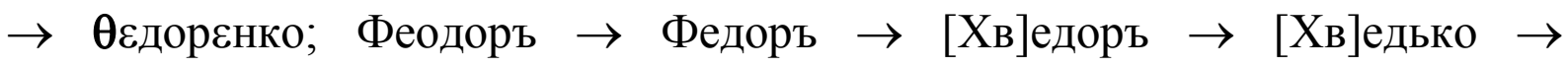
Хвєдчєнъко; Іувеналий $\rightarrow$ Ювеналий $\rightarrow$ Ювко $\rightarrow$ Ювъченъко; Иоакимъ(?) $\rightarrow$ Яким $\rightarrow$ Якимєнко; Иаковъ $\rightarrow$ Яковъ $\rightarrow$ Яковєнко; Иаковъ(?) $\rightarrow$ Яшко $\rightarrow$ Ященько; Маринъ $\rightarrow$ Мариныч; Афанасии $\rightarrow$ Апанас $\rightarrow$ Опанас $\rightarrow$ Опанасович. Таким чином, загальна кількість одиниць цієї підгрупи становить 29, 27 із яких утворені за допомогою патронімічного суфікса -енко-, 2 - за допомогою патронімічного суфікса -ич-, 1 - -ович-.

Сучасні патронімічні прізвища, в основі яких виступає канонічне ім'я, становлять також відносно велику групу: Василии $\rightarrow$ Василь $\rightarrow$ Василенко; Иоаннъ $\rightarrow$ Иоань $\rightarrow$ Іван $\rightarrow$ Івашко $\rightarrow$ Іващенко; Илия $\rightarrow$ Ілья $\rightarrow$ Ілько $\rightarrow$ Ільченко; Карп $\rightarrow$ Карпенко; Лазорь, Лазур(ь), ря, м.=Лазарь $\rightarrow$ 
Лазоренко [1, T. IV, с. 554]; Онисимъ $\rightarrow$ Онисько $\rightarrow$ Онищенко; Филиппъ $\rightarrow$ Филип $\rightarrow$ Пилипенко; Симеонъ $\rightarrow$ Сємєон $\rightarrow$ Семен $\rightarrow$ Сємєнєнко; Тихонъ $\rightarrow$ Тихоненко; Феодорь $\rightarrow$ Федоръ $\rightarrow$ Федоров; Феська, Феся, ж. $=$ Хвеська, Хвеся $\rightarrow$ Фесенко [1, Т. IV, с. 536].

Патронімічними вважаємо ПН $\mathrm{i}$ прізвища, утворені шляхом суфіксації від автохтонного слов'янського (дохристиянського) імені. ПН: Воронєнко $\leftarrow$ Ворон(а); Гучєнко $\leftarrow$ Гук (дикий птах); Дубинєня $\leftarrow$ Дубина (ім'я має так звану «профілактичну» функцію); Красючєнъко $\leftarrow$ Красюк (пор. Красун). Багато таких прізвищ можуть мати подвійну мотивацію: від нехрещеного імені або за характерною особливістю першого носія. Так само Бабичєнко: 1. бабич - «те саме, що бабій» [9, с. 527], 2. від автохтонного слов'янського імені: «базовими назвами прізвищ стали автохтонні слов'янські імена, утворені від термінів спорідненості, Бабич» [5, с. 185]; Вєрьгунєнко: 1. за характерною особливістю носія (твірна основа антропоніма могла бути пов'язана із семантикою апелятива «вергун - солодке печиво» [1, Т. I, с. 134], 2. від автохтонного слов'янського імені Вергун, що ввібрало семантику апелятива й мало побажальну функцію. Серед сучасних прізвищ також $є$ одиниці, мотивовані дохристиянськими іменами: Морозенко $\leftarrow$ Мороз; Сулименко $\leftarrow$ Сулимъ $\leftarrow$ Сулим [иръ] [2, с. 60]; Калиниченко $\leftarrow$ Калинка $\leftarrow$ Калина; Калинчук $\leftarrow$ Калина (подвійна мотивація: канонічне Кали́на, ж. Акилина [1, T. IV, с. 553], дохристиянське Кали́на [2, с. 28].

Твірною основою патронімічних ПН може виступати апелятив, що вказує на професію батька за професією батька: Бутєнъко - пор. бутъ «перекладач». На думку О. Горбача, апелятив «бут» тюркського походження: «3 тюркського - назва придунайського українського буткол (причому в першій частині слід здогадуватися османське put «ідол, хрест» як лайливої прізви християнина; з цим останнім, імовірно, в'яжеться й окреслення українсько-татарського перекладача «бут». Як зазначає П. Білецький-Носенко, словом буткалы (путкалы) називались запорізькі козаки в турецьких грамотах і трактатах від турків. М. Худаш фіксує антропонім Буть типу Голобуть, що є другою мотивацією твірної основи від дохристиянського імені [9, с. 532]. Також пор. 3 апелятивом «бутина». Так, аналізуючи прізвище Бутинець (що може бути пов'язане за семантикою з Бутєнъко, Бут), Ю. Редько зазначає, що воно вказує на спеціальність першого носія і означає людину, «що працює в бутині» [7, с. 135]. емъчєнъко - пор. емець, емъчикъ, патронімічні емъченъко, емчєнъковъ - пор. емєцъ, той, кому доручають від чийогось імені вести справу в суді, ємєцъ, споручникъ [9, с. 539]. Паламаренко - пор. паламар, пономар; paramonaris (служник, сторож) [11, с. 28]. Посошенко семантика твірної основи пов'язана з апелятивом посох (атрибут певних професій). Сотничєнко - пор. 3 військовою посадою (сотник). Стрышин 
(Стришин) - семантика твірної основи $є$ затемненою. Імовірно, походить від антропоніма Стрый (Стрых) (зустрічається в «Реєстрі...»), що в свою чергу може бути пов'язаний з апелятивами «стрих, ха, м. = стрихіль, ля, м. у кожевниковъ инструментъ для растягиванія кожи» [1, T. IV, с. 216], «стрий, стрия, м. дядя» [1, T. IV, с. 215]; таким чином, семантика твірної основи має подвійну мотивацію: 1. за професією першого носія; 2. за його характерною особливістю. Сурмачєнко - від «сурмач» - той, хто грає на сурмі. Шєвъчєнко - від професії швець.

У сучасних патронімічних прізвищах такі мотиваційні основи також представлені: Кравченко (кравець; за матеріалами Ю. Редька, зафіксоване в 14 областях) [8, с. 47]; Писаренко (писар; Ю. Редько вказує на значне поширення цього прізвища в Полтавській, Харківській, Чернігівській областях) [8, с. 39]; Рибальченко (рибалка); Чередниченко «(чередни́къ - 2 юж. нврс. пастухъ при чередь, при крупном скоть» [1, T. IV, с. 591]; череднйк - пастухъ стада рогатого скота; Чередниченко - сынъ чередника $[1$, T. IV, c. 465].

У межах цієї ж групи слід згадати ПН та прізвища, мотивовані апелятивами, що називають певну характерну особливість батька. Горкушєнъко - прізвищева назва походить, імовірно, від антропоніма Горкуша (зустрічається у функції прізвища у Реєстрі козаків), який у свою чергу походить від апелятива «гарку́ша, горку́ша», «той, хто гаркавить», Горъкавый - пор. гаркавий, «який вимовляє задньоязичне [р] замість передньоязичного» [9, с. 535, 536]; Зарубнєнко - пор. з апелятивом «за́руб $=$ зарубка - насічка» $[1$, T. II, с. 91] - семантика твірної основи залишається затемненою, хоча можливе припущення пов'язати семантику вищеназваного апелятива 3 якоюсь рисою вдачі або зовнішності чи відповідною ситуацією; Кулаженко - від апелятива «кула́га, ги, ж. родъ кушанья изъ муки» [1, Т. II, с. 322], пор. також «кула́га - пісна страва у вигляді густого киселю з борошна» [3, Т. III, с. 132] (пор. з мотивацією твірної основи прізвищевої назви Вєрьгунєнко); Лазчєнъко - семантика твірної основи затемнена, пор. 3 апелятивом «лазо́к, зка́ м. 1) грузило металлическое на сьтяхъ; 2) ум. отъ лаз; лаз, зу м. 1) преимущественно во мн.ч. лазаніе; 2) льсной проходъ звђрей; 3) льсная поляна у мн. нарђзки полей, участки» [1, Т. II, с. 341], імовірно, що значення прізвиська першого носія мало бути пов'язано з дієсловом лазити (пор. лаз - лазаніе); Макгурєнко - пор. макгура - «діал. ма́гура, ма́гура висока гора» [1, T. II, c. 396], характеристика за зовнішністю (зріст) першого носія; Патченко пор. «пати́к, ка́ м. палка; пати́ка, ки 1) палка; 2) кляча; 3) нерасторопный» (найбільш вірогідне) [1, Т. III, с. 101]; Покозбенко (Покорьенко) прізвищева назва Покорьенко, можливо, походить від апелятива «поко́ра, покорность, смирение» [1, Т. III, с. 274], тобто за певною рисою вдачі 
першого носія, однак темною виявляється семантика твірної основи прізвища Покозбенко, хоча це різночитання (пов'язані 3 технічними причинами) одного й того ж найменування; Страднєнъко - можливою є мотивація твірної основи за певною рисою вдачі людини; пор. страдний, страдник; Хирнєнъко - семантика твірної основи містить значення апелятива «хи́рний, a, e, 1) болђзненный, безсильный; 2) ничтожный, плохой, скверный» [1, T. IV, с. 398]. Сучасні прізвища із такою ж мотиваційною основою: Грачов - пор. 3 апелятивом «грач»; різні мотивації твірної основи; Пієнко - пор. 3 дієсловом пити; Світлугін - зовнішня характеристика.

Як бачимо, для патронімічних прізвищ обох періодів характерне виразне переважання утворень із суфіксом -енко, що свідчить про його стабільну продуктивність і регулярність на Полтавщині.

В антропонімії Полтавщини особливе місце посідають прізвища (ПН), що утворилися внаслідок функційних змін нехрещених імен. Із прийняттям християнства автохтонні імена здебільшого витіснялися i, змінюючи функцію, поступово ставали додатковим компонентом у системі ідентифікації особи. Головка - М. Демчук відносить цю особову назву до «імен та імен-прізвиськ 3 сумнівною або втраченою онімічною семантикою» і вважає, що імена від назв органів і частин людського тіла можна розглядати як «профілактичні, наприклад, щоб названий іменем Головка не страждав головними болями, був розумним» [2, с. 121]. Головъко - подвійна мотивація: 1. автохтонне слов'янське ім'я (аналогічно до Головка), хоча М. Худаш вважає, що антропоніми «такого типу важко пов'язувати 3 забобонними повір'ями» $[12$, с. 175]; 2. за характерною особливістю першого носія: Головъко - головко́, «головань» [3, Т. I, с. 551]; головко - «невеликий ростом 3 великою головою» [9, с. 536]. Головъня - подвійна мотивація: 1. автохтонне слов'янське ім'я «3 сумнівною або втраченою онімічною семантикою, дане за певною рисою зовнішнього вигляду, 3 профілактичним мотивом номінації» [2, с. 121]; 2. за характерною особливістю: пор. «головня 1) недопалений шмат дерева або той, що ще палає (також переносно про людину); 2) кольба, приклад. Пор. ще діал. голо́вня, «головешка» та ряд інш. значень» [9, с. 536]. Грудина, Грудына - подвійна мотивація: 1. автохтонні слов'янські імена 3 профілактичною функцією; 2. за характерною особливістю першого носія. Гукъ - подвійна мотивація: 1. автохтонне слов'янське ім'я «з сумнівною або втраченою онімічною семантикою 3 номенклатури тваринного світу, можна розцінювати як захисне, відстрашувальне «нечисту силу», оберігаюче від наврочень чи вживане як своєрідний «оберіг від хвороб» [2, с. 121]; від апелятива гук - дикий птах; 2. за характерною особливістю першого носія: семантика може бути пов’язана 3 апелятивом гук - дикий птах; «гукъ 1) гомін, галас; 2) натовп» 
[9, с. 536]. Дубина - подвійна мотивація: 1. автохтонне слов'янське ім'я 3 профілактичною функцією; 2. за характерною особливістю першого носія; пор. зі значенням «дурний». Мандрикъ - подвійна мотивація: 1. побажальне автохтонне слов'янське ім'я; «побажання благополуччя у житті, а щодо тих важких майже завжди голодних для простолюддя часів побажання постійно бути ситим, мати достаток у харчах або хоча б у якійсь конкретній їжі» [12, с. 174]; 2. за характерною особливістю першого носія; (людина, що полюбляла ці вироби або зовнішньо чи за вдачею мала якусь подібність до «мандрики» тощо); пор. «мандрика - паляниця з сиру, вид сирника, приготованого на розговини після Петрівки» [1, T.II, с. 404]. М. Худаш уважає це найменування відапелятивним утворенням i, на нашу думку, має рацію, бо такого типу відапелятивні утворення особливо були поширені в козацькому ономастиконі i, очевидно, час їх виникнення якраз припадає на часи козаччини. Мєдвєд - подвійна мотивація: 1. автохтонне слов'янське ім'я з відстрашувально-захисним мотивом називання; 2. за характерною особливістю першого носія або певною ситуацією, пов'язаною з цією твариною. Хмђл - подвійна мотивація: 1. автохтонне слов'янське ім'я «з сумнівною або втраченою онімічною семантикою» [2, с. 129]; 2. за характерною особливістю першого носія. Холод - подвійна мотивація: 1. автохтонне слов'янське ім'я, можливо, так само, як і Мороз, успадковане ще 3 праслов'янської доби; могло мати відстрашувальнозахисне значення або вказувати на час народження іменованих; 2. за характерною особливістю першого носія (семантично пов'язано 3 апелятивом холод). Хорошии - подвійна мотивація: 1. автохтонне слов'янське ім'я. На думку М. Худаша, «за кількістю і сортиментом чи не найбільше представлені власні імена, в яких укладені більш вузькі побажання дитини, найчастіше якоїсь позитивної риси у зовнішньому вигляді або поведінці, психіці, характері» [12, с. 173]; 2. за рисою вдачі, характеру першого носія. Чернята, Чорнышъ - за архівними даними М. Демчук, ці найменування $є$ суфіксальними відкомпозитними утвореннями імен типу Чернигои, Чорнобыть [2, с. 60]. Слушною видається і думка, що причиною вибору нехрещеного власного імені типу Чорниш (Черниш) стала відповідна характерна риса зовнішнього вигляду дитини [12, с. 164]. Так само подвійну мотивацію мають найменування: Безрукии, Безушко, Криворукии, Косыи: 1. автохтонні слов'янські імена, що мали профілактичну функцію; 2. за характерною особливістю, фізичною вадою першого носія.

Із масиву аналізованих сучасних прізвищ виділяємо 17 одиниць, мотивованих автохтонними іменами. 3 огляду на обмежений обсяг роботи подаємо лише найцікавіші для аналізу. Верещака - подвійна мотивація: 1. нехрещене ім'я. Такого типу імена часто спрямовані на захист i відвертання від дитини, звичайно, молодшого віку, тих чи інших проявів негативної поведінки або вдачі, наприклад, плаксивості. М. Демчук також 
вважає, що це ім'я, дане за певною рисою характеру, поведінки і $\epsilon$ негативною назвою 3 профілактичним мотивом номінації [2, с. 118]; 2. прізвище виникло безвідносно до нехрещеного імені та характеризувало першого носія за характерною особливістю характеру, поведінки. Кваша можлива подвійна мотивація: 1. нехрещене ім’я «з сумнівною або втраченою онімічною семантикою», від назви страви або продукту харчування [2, с. 117, 131], 2. за певною характерною особливістю першого носія. Мороз - нехрещене ім'я, успадковане через давньоруське посередництво ще 3 праслов'янської доби. Звичай давати такі імена в побуті українського народу існував і до кінця XIV - XVII століть - ім'я Мороз було особливо поширеним і могло мати відстрашувально-захисне значення, хоч частіше вказувало на час народження іменованих [2, с. 28, 29; 29, с. 170]. Олешко - як нехрещене ім'я це прізвище виступало у пам'ятці Реєстру Війська Запорізького 1649 року. П'ятуха - автохтонне ім'я, що вказує на черговість народження дитини в сім’ї, має відтінок насмішливості чи зневажливості.

До третьої групи ПН належать такі одиниці: Жовнинскии (відтопонімічна; пор. Сотьня Жовнинская Чигиринський полк), сучасне с. Жовнине Чорнобаївського району Черкаської обл. [9, с. 540]; Крємєнчуцкии від м. Кременчук Полтавської обл.; Матяшовскии (2 одиниці) від топоніма; пор. сучасні с. Матяшівка Великобагачанського району Полтавської області і с. Матяшівка Лубенського району Полтавської обл. [9, с. 551]; Чугуевєц - пор. сучасне м.Чугуїв у Харківській обл. [9, с. 584]; Яресковъський - пор. сучасне м. Яреськи у Полтавській обл. [9, с. 566]; Счєпєтовскии - темна семантика. Сучасні прізвища: Зеленський - пор. сучасні назви сел Зеленівка, Зеленьки, Зеленче Херсонської обл.); Лях - подвійна мотивація: 1. етнічне прізвище; належність до народності, означення національності пращура; 2. прізвище, утворене за характерною особливістю першого носія, що міг бути схожий зовнішньо або поведінкою на ляха. Черкас - аналогічно до прізвища Лях.

До «професійних» ПН відносимо такі: Рибалка, Шевчик, Бут (3 одиниці). М. Худаш вказує на таку цікаву деталь щодо прізвища Шевчик: «підмастери або мало кваліфіковані майстри, яких цехова верхівка називала партачами, фігурували у різних документах переважно лише під власними іменами та прізвиськами. Якщо ж у їхній ідентифікації й значиться назва за фахом, то здебільшого в похідній формі на -ик (типу Шевчик...)» [12, с. 134]. Бут (3 одиниці) - подвійна мотивація: 1. за професією; 2. автохтонне слов'янське ім'я відкомпозитного походження типу Голобутъ.

Сучасних прізвищ у цій підгрупі більше порівняно зі старими (4 i3 64, 3 iз 120 відповідно), що, очевидно, пов'язано 3 розширенням ремесленної діяльності й подальшим розвитком традиції називати людину за професією. Бондаревський - «Бочки й бодні майстрували боднарі (або 
бондарі). Назва, в якій відбулася метатеза приголосних, типова для східних областей, і в прізвищах вона там також поширена. У сучасній літературній мові пізніша форма «бондар» витіснила первісну «боднар». Від обох варіантів утворилися також похідні прізвища» [8, с. 46]. Не можна відкидати й відтопонімного походження. Колісник; Кравчун - виникнення цього прізвища, на думку Ю. Редька, припадає приблизно на XVII - другу половину XVIII ст. і пов'язано з економічним життям країни. Кучер можлива подвійна мотивація: 1. професійне прізвище (запозичення 3 німецької - Kutscher), фурман; 2. за характерною особливістю першого носія безвідносно до професії кучера. Можливо, від «кучер» у значенні волосся, тобто людина, що мала кучері, або ж зі значення певної властивості характеру (наприклад, звичка так говорити тощо).

Одним із поширених мотивів найменування $є$ характерна особливість чи вада першого носія. ПН: Волевачъ (пор. «вольовий»); Горкуша; Дちжечка (затемнена семантика та мотив називання); Дуда - можливі дві мотивації: 1. автохтонне слов'янське ім'я 3 сумнівною або втраченою онімічною семантикою; 2. за характерною особливістю першого носія; Кишканъ (пор. діал. кишка́нь «чоловік з одним ядром») [3, Т. II, с. 441]; Лєжень - подвійна мотивація: 1. за характерною особливістю першого носія( пор. 3 дієсловом лежати), наприклад, за певною вадою (лінивий, той, що багато лежить); 2. автохтонне слов'янське ім'я (з профілактичним мотивом). Цяпко - пор. «ца́пкі́ й 1) хапкий, чіпкий; 2) схильний до крадіжок, хабарництва» [9, с. 563]; Шелест - подвійна мотивація: 1. за характерною особливістю першого носія (пор. 3 дієсловом шелестіти); 2. автохтонне слов'янське ім'я з профілактичною функцією.

Такий мотив номінації не втрачав актуальності й надалі, про що свідчать сучасні прізвища: Білик - подвійна мотивація: 1. за кольором волосся; 2. іменування за нехрещеним власним ім'ям, пор. ББликъ [12, с. 115]; Бобирь - затемнена семантика, можливо, за зовнішньою ознакою; Бурик: 1. за кольором волосся, 2. за рисою характеру; Виплавень - називання могло бути пов'язане із певним випадком, що стався 3 першим носієм (пор. 3 дієсловом випливати); Глушич - за фізичною властивістю. Лиходід - антропонім 3 атрибутивносубстантивною основою, М. Лесюк зазначає, що більшість особових назв козаків покликана була давати якісну характеристику особі, підкреслюючи iii ті чи інші властивості й риси [4, с. 168]. Також до козацьких прізвищ за походженням відносить антропоніми такого типу i М. Худаш [13]. Одновіл - можливо, перший носій мав у господарстві лише одного вола; Падалка - семантика $є$ затемненою, пор. з апелятивом: «падалка - те саме, що падалиця: 1) плоди або листя, які опали з дерев, 2) незібране, опале зерно, насіння і таке інше, що залишилось в полі // рослина, що виросла 3 опалого зерна, насіння»[10, T. VIII, с. 78]. Перетятько - можливо, 
називання за певною фізичною властивістю. Семергей - подвійна мотивація: 1. за характерною особливістю: пор. «сдма̄pli тюрк. - грубый, вульгарный; 2. за професією: пор. сдмерli тюрк. - фабрикантъ и продавецъ вьючных сьделъ» $[6$, T. IV, с. 510]. Снаговський - за певною фізичною властивістю; людина, що має силу, снагу. Срібна - подвійна мотивація: 1. за кольором волосся (тотожне за значенням - сивий, сива); 2. багата або навпаки бідна (т.зв. «зворотне» називання) людина. Ступа - за розумовими властивостями першого носія: пор. фразеологізм «дурний як ступа».

На підставі аналізу фактичного матеріалу можемо зробити певні узагальнення. Для прізвищ обох періодів (і XVII ст., і сучасного) однаково важливу роль відіграє взаємозв'язок семантичного і словотвірного аспектів дослідження. Це виявляється в тому, що при виділенні семантичної групи патронімічних (та матронімічних) прізвищ враховується формальна структура (наявність так званих патронімічних (і матронімічних) суфіксів, зокрема -енко-, -ов- (-ич-), -ін-, -шин-, -чук-), при словотвірному аналізі слід зважати на семантику, оскільки досліджувані одиниці, віднесені до II-ї семантичної групи (функційна зміна нехрещених імен), можуть бути утворені лексико-семантичним способом (хоча за формальними показниками це суфіксація або синтаксично-морфологічний спосіб, наприклад, Головка, Криворукии, Чєрнята (XVII ст.); Білик, Чорнуха (сучасні)). Виразно простежується наявність прозорої i напівтемної (темної) семантики антропонімів (наприклад, Макаренъко, Петренъко (прозора), Баиманъ, Чучуи (темна) (XVII ст.), Василенко, Писаренко (прозора), Дядик (темна) (сучасні); можливість подвійної мотивації (i семантичної, і словотвірної). (Наприклад, Чорнята, Безрукии (XVII ст.); Бойко, Чорнуха (сучасні)). Кількісно найбільшою для обох періодів $\epsilon$ семантична група (патронімічні прізвища), у яких переважають утворення 3 суфіксом -енко- (62 прізвищеві назви зі 120; 20 прізвищ із 64), що свідчить про закономірність послідовного використання цього форманта для творення прізвищ (прізвищевих назв) у східних областях, зокрема в Полтавській, вже у XVII ст. і до сучасності. Також слід зазначити, що для давнього періоду характерна частіша вживаність суфікса -енко- (більше половини від загальної кількості найменувань утворені за допомогою цього форманта), ніж для сучасності (лише приблизно третина). Таку схильність до одноманітності прізвищевих назв XVII ст. можна пояснити меншим ступенем міграції населення різних областей (країн) і відповідно меншим впливом іменувань інших типів на тип полтавського регіону (наприклад, у прізвищевих назвах XVII ст. нема жодної з суфіксом -чук(типовим для західних областей), на відміну від сучасних прізвищ (Калинчук)). У XVII ст. система прізвищ (і взагалі ідентифікації особи) ще не була остаточно сформована в сучасному розумінні (наявність різночленних утворень, серед яких найбільше двочленних, мішаних іменувань типу Дмитров зять), однак можна твердити, що в цей час були 
вже закладені основи цієї системи, про що свідчить можливість виділення схожих семантичних та словотвірних груп, застосування однієї класифікаційної схеми для аналізу прізвищевих назв і прізвищ. Давні слов'янські патронімічні (раніше посесивні) суфікси типу -ов-, -ого- у прізвищевих назвах зустрічаються тільки в мішаних (антропонімійноапелятивних) іменуваннях, на відміну від сучасних прізвищ: пор., наприклад: Денисов брат, Пђсоцкого зят (XVII ст.) та Грачов, Федоров (сучасні). Такий факт свідчить про неусталеність системи найменуваннь у XVII ст., а також про те, що процес «відкидання» допоміжних апелятивів іще не мав значного поширення.

\section{Література}

1. Грінченко Б. Словарь української мови : у 4-х т. / Б. Грінченко. - К. : Вид. АН УРСР, 1958.

2. Демчук M.О. Слов'янські автохтонні особові власні імена в побуті українців XIV - XVII ст. / М. О. Демчук. - К. : Наук. думка, 1988. - 169 с.

3. Етимологічний словник української мови : у 7-и т. / [редк. О. С. Мельничук (гол. ред.) та інші]. К. : Наук. думка, $1982-1989$.

4. Лесюк М. Козацькі прізвища відкомпозитної структури і їх сліди в сучасній українській антропонімії / М. Лесюк // Siowiańskie composita antroponimiczne / Pod redakcj№ Stefana Warchoia. Lublin : Wydawnictwo Uniwersytetu Mariï Curie - Skiodowskiej, 2000. - C. 247 -259.

5. Ономастика України першого тисячоліття нашої ери / [під ред. І. М. Железняк]. - К. : Наук. думка, 1992. $-272 \mathrm{c}$.

6. Радлов В. В. Опыт словаря тюркских наречий : у 7-и т. / В. В. Радлов. - М. : Изд. вост. лит., 1963.

7. Редько Ю. К. Назви професій як основа виникнення частини українських родових прізвищ / Ю. К. Редько // Дослідження і матеріали з української мови. - К. : Наук. думка, 1959. - Т. I - С. 127 - 136.

8. Редько Ю. К. Сучасні українські прізвища / Ю. К. Редько. - К. : Наук. думка, 1966. - 216 с.

9. Реєстр Війська Запорозького 1649 року : Транслітерація тексту / [НАН України, Археогр. коміс. та інш.; підг.: О. В. Тодійчук (гол. упоряд.) та інш.]. - К. : Наук. думка, 1995. - 558 с.

10. Словник української мови : в 11-и т. / [І. К. Білодід, А. А. Бурячок та ін.]. - К. : Наук. думка, 1970 $-1980$.

11. Сухомлин І. Д. 3 історії українських прізвищ / І. Д. Сухомлин // Українська мова і література в школі. - 1965. - №4. - С. $24-28$.

12. Худаш М. Л. 3 історії української антропонімії / М. Л. Худаш. - К. : Наук. думка, 1977. - 233 с.

13. Худаш М. Л. Українські козацькі особові назви (композити і словосполучення) XVII ст. / М. Л. Худаш // Ономастика. - К. : Наук. думка, 1966. - С.136 - 145. 